\title{
Erratum to: Atmospheric conditions during high ragweed pollen concentrations in Zagreb, Croatia
}

\author{
Maja Telišman Prtenjak • Lidija Srnec • \\ Renata Peternel • Valentina Madžarević • Ivana Hrga • \\ Barbara Stjepanović
}

Published online: 8 June 2012

(C) ISB 2012

\section{Erratum to: Int J Biometeorol}

DOI: 10.1007/s00484-012-0520-3

The correct correspondence address for the last named author, Barbara Stjepanović, should be "Dr. Andrija Štampar" Institute of Public Health, Zagreb, Croatia

The online version of the original article can be found at http://dx.doi.org/ 10.1007/s00484-012-0520-3.

\section{T. Prtenjak $(\varangle) \cdot$ V. Madžarević}

Andrija Mohorovičić Geophysical Institute,

Department of Geophysics, Faculty of Science, University of Zagreb,

Horvatovac 95,

10000 Zagreb, Croatia

e-mail: telisman@gfz.hr

L. Srnec

Meteorological and Hydrological Service of Croatia, Zagreb,

Croatia,

Grič 3,

10000 Zagreb, Croatia

R. Peternel

University of Applied sciences Velika Gorica,

Velika Gorica, Croatia

I. Hrga $\cdot$ B. Stjepanović

"Dr. Andrija Štampar" Institute of Public Health,

Zagreb, Croatia 